\title{
IMPLEMENTATION OF PROVISION OF ASSIMILATION IN THE TIME OF COVID-19 FOR PRISONERS
}

\author{
Dwi Seno Wijanarko
}

Bhayangkara University Jakarta Raya, Indonesia

Email: dwi.seno@dsn.ubharajaya.ac.id

\begin{tabular}{|c|c|}
\hline ARTICLE INFO & ABSTRACT \\
\hline $\begin{array}{l}\text { Received: } \\
\text { January, } 26^{\text {th }} \\
2022 \\
\text { Revised: } \\
\text { February, 17th } \\
2022 \\
\text { Approved: } \\
\text { February, } 18^{\text {th }} \\
2022\end{array}$ & $\begin{array}{l}\text { A criminal act committed by a person does not eliminate his } \\
\text { human dignity, so that his position as a prisoner does not } \\
\text { prevent him from getting guaranteed protection and } \\
\text { fulfillment of human rights. This provision then animates } \\
\text { the existence of a correctional system with a set of } \\
\text { accompanying legal instruments, including a coaching } \\
\text { system which is embodied in the form of an assimilation } \\
\text { program. As part of the prisoner development system, the } \\
\text { implementation of assimilation has faced challenges during } \\
\text { the COVID-19 pandemic. Departing from the description } \\
\text { above, the researcher intends to conduct research related } \\
\text { to the implementation of assimilation during the COVID-19 } \\
\text { pandemic by placing the research locus in Cipinang Class I } \\
\text { Prison. The objectives to be achieved in this research are: } 1) \\
\text { Knowing the process of providing assimilation for prisoners } \\
\text { in Cipinang Class I Correctional Institution; } 2 \text { ) Knowing the } \\
\text { impact resulting from the provision of assimilation for } \\
\text { prisoners in the Cipinang Class I Correctional Institution. } \\
\text { The type of research used in this study is empirical legal } \\
\text { research which bases research on findings in the field, so } \\
\text { the approach used in this research is a sociological juridical } \\
\text { approach. The results of this study are first, the } \\
\text { implementation of assimilation in Cipinang Class } 1 \text { Prison is } \\
\text { based on the Regulation of the Minister of Law and Human } \\
\text { Rights of the Republic of Indonesia Number } 10 \text { of } 2020 \text {. } \\
\text { Based on this legal source, Cipinang Class } 1 \text { Prison has given } \\
\text { as many as } 533 \text { assimilation rights to prisoners. Second, the } \\
\text { provision of assimilation carried out during the Covid-19 }\end{array}$ \\
\hline
\end{tabular}

Dwi Seno Wijanarko. (2022). Implementation of Provision of

Assimilation in the Time of Covid-19 for Prisoners. Journal Eduvest.

How to cite:

Vol 2(2): 190-195

E-ISSN:

2775-3727

Published by: https://greenpublisher.id/ 


\begin{tabular}{ll}
\hline & $\begin{array}{l}\text { pandemic subsequently brought positive and negative } \\
\text { impacts at the same time. }\end{array}$ \\
\hline KEYWORDS & Assimilation, Coaching, Covid-19 Pandemic \\
\hline CC) (i) (9) & $\begin{array}{l}\text { This work is licensed under a Creative Commons } \\
\text { Attribution-ShareAlike 4.0 International }\end{array}$ \\
\hline
\end{tabular}

\section{INTRODUCTION}

The correctional system is an order regarding the direction and limits as well as the method of fostering prisoners based on Pancasila which is carried out in an integrated manner between the coaches, who are fostered and the community to improve the quality of prisoners so that they realize mistakes, improve themselves, and do not repeat criminal acts so that they can be accepted again by the community can live as good and responsible citizens (Danial, Masyitoh, \& Tanshzil, 2020). One of the important components in the correctional system is the Correctional Institution or Prison (Pont et al., 2018). Correctional institutions ideally contain the intention to re-socialize the inmates who have violated the laws and norms adopted by the community (Ananda, 2021) (Muslim, 2020). The purpose of this institution is to change the nature, way of thinking and behavior, the process of educative interaction must be built (Oke \& Fernandes, 2020). Intensive educative interaction is very much needed, so that collectively the inmates' awareness grows about the behavior that should be carried out (Abdulkareem, Augustijn, Filatova, Musial, \& Mustafa, 2020).

The term correctional institution can be equated with resocialization with the understanding that everything is placed in the Indonesian cultural system with the values that apply in Indonesian society (Sumpter, Wardhani, \& Priyanto, 2021). Based on this, correctional facilities, both in terms of systems, institutions, coaching methods, and correctional officers, are an inseparable part of a series of law enforcement processes (Smith, 2020). The position of the correctional institution as a coaching institution in the criminal justice system is very strategic in realizing the ultimate goal of the criminal justice system, namely the rehabilitation and resocialization of lawbreakers, even to the suppression of crime. One of a series of correctional programs carried out in correctional institutions is the coaching process given to prisoners (Stasi et al., 2022). Prison coaching aims to prepare inmates in prison so that they can interact in a healthy manner with the community, so that they can play a role again as free and responsible members of society (Ertl et al., 2019).

Based on data from the Directorate General of Corrections, the number of prisoners and detainees in Indonesia as of April 11, 2020 has reached 225,176 people, while the total prison capacity is only for 132,107 inmates and detainees. According to World Prison Brief data, prisons in Indonesia are overcapacity by $104 \%$. On this basis, the government then took action to release prisoners who had complied with the applicable laws and regulations through assimilation and integration media, as an effort to prevent the massive spread of the virus. As of April 20, 2020, the number of adult and child prisoners released through the assimilation and integration program has reached 36,554 people and is confirmed to continue to grow.

The policy of releasing prisoners through assimilation as an effort to prevent the transmission of Covid 19 then gave rise to various controversies in the community. Considering that this policy can cause several new problems, such as: First, in the midst of the COVID-19 pandemic, ex-convicts will be faced with a difficult situation to find work. Second, the widespread practice of buying and selling tickets for the release of 
prisoners in prisons. Third, criminal acts began to emerge. The riots in Manado prison due to social jealousy did not get assimilated and the actions of the released prisoners became one of the evidences. According to data from the Directorate General of Corrections, it is proven that 12 prisoners have committed crimes again after previously being released through assimilation.

\section{RESEARCH METHOD}

The type of research used in this research is empirical research. Empirical research is research that places data in the field as the main data source (Mao \& Lee, 2020). This type of research is usually used to analyze the law which is seen as patterned community behavior in a social life that interacts and relates to one another (Allan, 2021).

This research is included in the clustering of empirical research because this research will focus on the reality in the field to be able to find out the form of protection of the rights possessed by prisoners through the provision of assimilation in Cipinang Class I Penitentiary during the pandemic. So it is hoped that this research can provide a chronological understanding of giving assimilation (Tran \& Birman, 2019).

The approach used in this research is a sociological juridical approach (Timans, Wouters, \& Heilbron, 2019). The sociological juridical approach is to identify and conceptualize law as a real and functional social institution in a real life system. As for this research, the data is presented in the form of narrative text (Budianto, 2020).

\section{RESULT AND DISCUSSION}

\section{A. The Process of Providing Assimilation for Inmates in Cipinang Class I Correctional Institution}

1. Overview of Cipinang Class 1 Penitentiary

As a Class I prison, Cipinang is one of the oldest correctional institutions that has been present since 1921 as the starting point for the separation of prisons based on crime levels, gender, and age. Initially referred to as the Cipinang Prison, which was devoted to male inmates who were included in the adult category. LP Cipinang was born in the third correctional period, which began with the Correctional System Evaluation Workshop in 1975. The workshop discussed several issues related to the legal basis and operational structure of the correctional facility, including the return of the name from bina tuna Warga to correctional facilities according to the original concept.

The following services are provided: 1) Domestic cooperation; 2) Foreign cooperation; 3) Research permit services; 4) Information services to the public; 5) Information service to mass media; 5) Services in the field of security and order, including complaint services; 6) Services in the field of coaching which include: counseling, provision of reading materials, education, transfer, parole, legal consultation, request for leave to visit family, etc.

2. Implementation of Assimilation for Prisoners in Cipinang Class I Correctional Institution

The dynamics of legal changes in the implementation of assimilation which was felt to be running fast were also felt by the Cipinang Class I Penitentiary. Where based on the new provisions, Cipinang Class I Prison also bases all actions related to granting assimilation based on the provisions contained in the Regulation of the Minister of Law 


\section{Dwi Seno Wijanarko}

and Human Rights of the Republic of Indonesia Number 32 of 2020 in conjunction with the Regulation of the Minister of Law and Human Rights of the Republic of Indonesia Number 24 of 2021. As one of the One of the rights possessed by prisoners with respect to their position as humans who are currently serving a sentence due to criminal acts committed, correctional institutions are required to provide guidance to prisoners. The guidance is given as a form of state commitment in interpreting the provision of punishment not only intended as giving suffering, but also as an instrument to be able to prepare prisoners' lives in a more orderly and directed society.

\section{B. The Impact of Providing Assimilation for Inmates in Cipinang Class I Prison during the Pandemic}

The condition of the Covid-19 pandemic which then presents its own obstacles in the process of implementing assimilation. These obstacles can then be identified as follows:

1) The level of spread of covid-19 which requires the public to place restrictions on locations and activities, so that it also has an impact on efforts to limit activities related to the implementation of assimilation;

2) The difficulty of establishing communication and cooperation with the Partner Team in the implementation of assimilation;

3) The guarantor's family who is not intensive and cooperative in providing information and information related to the guaranteed prison inmates;

4) The fear of another violation of the law by prisoners makes the kelurahan or other names reluctant to sign the administrative requirements file.

The difficulty of establishing cooperative communication with the guarantor's family, in practical terms also has an impact on the weakening of the supervision system carried out by correctional institutions. Where in terms of supervising the implementation of assimilation, the prison will coordinate with the prison. Systemically, after undergoing home assimilation, all files will be submitted to the prison for further management and implementation of a monitoring program in the form of: mandatory reporting once a month, video calls, and communication with the guarantor's family regarding the development of prisoners outside the prison.

\section{CONCLUSION}

The implementation of assimilation carried out at the Cipinang Class I Penitentiary during the COVID-19 pandemic was based on the Regulation of the Minister of Law and Human Rights of the Republic of Indonesia Number 10 of 2020 concerning Conditions for Providing Assimilation and Integration Rights for Prisoners and Children in the Context of Prevention and Control of the Spread of Covid-19. The assimilation program based on these rules is hereinafter referred to as home assimilation. Throughout the application of the above ministerial regulation as a source of law, Cipinang Class I Prison has provided an assimilation program to 533 inmates. With regard to the supervision system carried out in home assimilation, the prison team coordinates with the Fathers and the family to ensure that prisoners who receive assimilation carry out the program well.

In its implementation, the assimilation provided as one of the coaching programs during the pandemic presents two impacts, namely positive impacts and negative impacts. The positive impact of implementing assimilation during the pandemic is the large 
number of prisoners receiving assimilation programs considering that the requirements stated in the latest regulations are relatively easier than the previous regulations. The more inmates who get this program will reduce the number of overludes in prisons. In addition, from the number of prisoners who received the assimilation program, it was recorded that only one prisoner returned to prison as a recidivist. This figure shows that the implementation of assimilation in Cipinang Class I Prison is running effectively. The negative impact of implementing assimilation during a pandemic is the increasing obstacles in the provision and implementation of assimilation not only on internal and external factors, but also obstacles in terms of the massive spread of the COVID-19 virus. So many activities related to coaching must be canceled to control the spread of the Covid-19 virus.

\section{REFERENCES}

Abdulkareem, Shaheen A., Augustijn, Ellen Wien, Filatova, Tatiana, Musial, Katarzyna, \& Mustafa, Yaseen T. (2020). Risk perception and behavioral change during epidemics: Comparing models of individual and collective learning. PloS One, $15(1), \mathrm{e} 0226483$.

Allan, Graham A. (2021). A sociology of friendship and kinship. Routledge.

Ananda, Azzahra Rizki. (2021). Correctional Institution's Construction In The DeathConvicted Supervision. Pancasila and Law Review, 2(1), 1-14.

Budianto, Agus. (2020). Legal Research Methodology Reposition in Research on Social Science. International Journal of Criminology and Sociology, 9, 1339-1346.

Danial, Endang, Masyitoh, Iim Siti, \& Tanshzil, Sri Wahyuni. (2020). Education for All Citizens. 2nd Annual Civic Education Conference (ACEC 2019), 500-502. Atlantis Press.

Ertl, Tanja, Taugerbeck, Sebastian, Esau, Margarita, Aal, Konstantin, Tolmie, Peter, \& Wulf, Volker. (2019). The social mile-How (psychosocial) ICT can help to promote resocialization and to overcome prison. Proceedings of the ACM on HumanComputer Interaction, 3(GROUP), 1-31.

Mao, Zhicheng, \& Lee, Icy. (2020). Feedback scope in written corrective feedback: Analysis of empirical research in L2 contexts. Assessing Writing, 45, 100469.

Muslim, Ichwanul Fauzi. (2020). Pre-Release Treatment in Class II A Correctional Institution of Pekalongan. Journal of Law and Legal Reform, 1(1), 93-106.

Oke, Adekunle, \& Fernandes, Fatima Araujo Pereira. (2020). Innovations in teaching and learning: Exploring the perceptions of the education sector on the 4th industrial revolution (4IR). Journal of Open Innovation: Technology, Market, and Complexity, $6(2), 31$.

Pont, Jörg, Enggist, Stefan, Stöver, Heino, Williams, Brie, Greifinger, Robert, \& Wolff, Hans. (2018). Prison health care governance: guaranteeing clinical independence. American Journal of Public Health, 108(4), 472-476.

Smith, Hayden P. (2020). Evaluating the implementation of the prison rape elimination act (prea): A "lessons learned" approach. Evaluation and Program Planning, 83, 101855

Stasi, Cristina, Monnini, Mirko, Cellesi, Valerio, Salvadori, Marco, Marri, Daniele, Ameglio, Mateo, Gabbuti, Andrea, Celmi, Rossella, Di Fiandra, Teresa, \& Voller, Fabio. (2022). Ways to promote screening for hepatitis B virus and accelerated vaccination schedule in prison: Training, information, peer education. Revue d'Épidémiologie et de Santé Publique. 
Dwi Seno Wijanarko

Sumpter, Cameron, Wardhani, Yuslikha K., \& Priyanto, Sapto. (2021). Testing transitions: Extremist prisoners re-entering Indonesian society. Studies in Conflict \& Terrorism, 44(6), 473-494.

Timans, Rob, Wouters, Paul, \& Heilbron, Johan. (2019). Mixed methods research: what it is and what it could be. Theory and Society, 48(2), 193-216.

Tran, Nellie, \& Birman, Dina. (2019). Acculturation and assimilation: A qualitative inquiry of teacher expectations for Somali Bantu refugee students. Education and Urban Society, 51(5), 712-736. 